\title{
Morphology and histology of the female reproductive system of the mangrove land crab, Ucides cordatus (Linnaeus, 1763) (Brachyura: Ocypodidae)
}

Flávia Duarte Ferraz Sampaio, Tania Mara Simões do Carmo and Assunta Maria Penna

(FDFS) Grupo Integrado de Aqüicultura e Estudos Ambientais C P. 19073, Universidade Federal do Paraná, Curitiba, PR 81531-990, Brazil. Corresponding author. E-mail: fdfsampaio@hotmail.com

(TMSC) Departamento de Ciências Biológicas da Universidade Federal do Espírito Santo. (AMP) Escola Superior de Ciências da Santa Casa de Misericórdia de Vitória.

\section{Abstract}

This study provides a detailed description of the macro- and microscopic anatomy of the female reproductive system of the mangrove land crab, Ucides cordatus. A total of 277 females were collected between October 1998 and September 1999 in mangroves of the Victoria Bay, State of Espírito Santo, Southeast Brazil. The reproductive system of this species is composed of two ovaries united together by a bridge, present in the form of an $\mathrm{H}$ when viewed dorsally, and two seminal receptacles. Histological analysis revealed the following six stages of oocyte development: I. young germ cells (oogonias); II. oocytes of the germinative centers; III. oocytes with lipid vitellogenesis; IV. vitellogenic oocytes with lipid and protein; V. oocytes with completed vitellogenesis; and VI. oocytes in hyalinization. The anatomy of the ovary is characterized by the following six stages of development: I. immature; II. at maturity; III. mature; IV. partly spawned; V. fully spawned; and VI. in recovery. Reproduction was observed in summer, and the results suggesting that this species showed multiple spawnings.

Key words: Anatomy, histology, mangrove crab, oogenesis, reproduction

\section{Introduction}

The mangrove land crab, Ucides cordatus (Linnaeus, 1763), is found exclusively in mangrove ecosystems around the world (Alcântara-Filho, 1978). It is distributed along the western Atlantic coast from Florida (U.S.A.) to Brazil. In Brazil, it is found from the states of Para to Santa Catarina (Melo, 1996). This species undergoes its entire reproductive cycle in the mangrove ecosystem (Nascimento, 1993). The mangrove land crab is the main economic means for low-income families (Vale, 1994; Alves and Nishida, 2004), and many communities survive due to this resource (Nordi, 1995).

In a specific phase of the reproductive cycle, $U$. cordatus leave their burrows and drift on the surface of the mangroves. This phenomenon is known as "andada" (AlcântaraFilho, 1978; Costa, 1979; Nascimento, 1993). The "andada" is a type of reproductive migration and usually occurs from December through May during a three- to four-day 
period of each month (Alcântara-Filho, 1978; Costa, 1979).

The external morphology of the female reproductive system of $U$. cordatus in Brazil was first described by Mota-Alves (1975) and further research has also focused on the species (Alcântara-Filho, 1978; Nascimento, 1993; Dalabona and Loyola-Silva, 2005; Sant'Anna et al., 2007). Nakamura (1979) described the macro- and microscopic morphology of the ovaries, and Dalabona and Silva (2005) investigated the reproductive period of $U$. cordatus based on macroscopic observation and gonad histology.

This study is part of the Crab Project, developed by the Federal University of Espirito Santo with the aim of studying the bioecology of $U$. cordatus and the socioeconomic conditions of crab harvesters. Thus, the goal of the present study was to provide a description of the macro- and microscopic anatomy of the female reproductive system of the mangrove land crab, clearly explaining the differences between these findings and those of previous studies of $U$. cordatus.

\section{Materials and Methods}

Females of $U$. cordatus were collected monthly from October 1998 to September 1999 in mangroves of Victoria Bay, State of Espírito Santo, Southeast Brazil (approximately latitude $20^{\circ} 14$ ' 20"S - 40 $\left.10^{\circ} \quad 30^{\prime \prime} \mathrm{W}\right)$. All individuals were collected manually. All specimens were transported alive to the laboratory where they were kept in aquaria (150 l) with mangrove sediment and held for further processing.

The crabs were kept at $-10^{\circ} \mathrm{C}$ for approximately $15 \mathrm{~min}$ to reduce their metabolism. The metabolic status of the crabs was indicated by the degree of lethargy that they exhibited. The carapace width of each individual was measured with calipers. The carapace was then removed. The reproductive system of each specimen was completely dissected and its morphology described. Developmental stages of the ovary were based on their shape, coloration and volume occupied in the carapace cavity (Mota-Alves, 1975; Nakamura, 1979). The histological analysis and the classification of the type of spawning were described according to Vazzoler (1996). Females were ovigerous if they had eggs in the pleopods. The mass of eggs was weighed, and the presence of eggs in the pleopods was recorded.

The histological processing was performed in the Histologic Processing Laboratory, Department of Morphology of the Biomedical Center of the Federal University of Espirito Santo State. Fragments of the ovaries were fixed in Bouin's fixative for $24 \mathrm{~h}$ and processed according to standard histological methods (Junqueira and Junqueira, 1983). The tissues were sectioned into $10 \mu \mathrm{m}$ slides using an American Optical microtome, model 840 Rotary. Permanent slides were stained with hematoxylin and eosin (HE). Following this procedure, the material was mounted in Canada Balsam (Cajal and Castro, 1972; Lillie and Fulmer, 1976). The slides were examined, selected, described and photographed.

\section{Results}

Two-hundred and seventy-seven females (17.3-77.5 mm carapace width) were processed. The female reproductive system consists of two ovaries united by a bridge. The bridge has the form of an $\mathrm{H}$ if viewed dorsally. The reproductive system occupies the cephalothorax cavity from the anterior to the posterior. The reproductive system extends only to the extreme portions of this cavity. Each ovary continues to be the one oviduct that leads into the genital opening located on the 6rd thoracic sternite at the 3rd pair of legs. There are two seminal receptacles, in which sperm are stored after mating. The seminal receptacles are a specialization of the oviduct. Macroscopically, they have an oval shape and a white color.

Histological analysis revealed the following six stages of oocyte development:

I. Young germ cells (oogonias): nucleus 
intensely basophilic with only central nucleolus and chromatin attached to the membrane (Fig. 1A).

II. Oocytes of the germinative centers: little cytoplasm, faintly stained by $\mathrm{HE}$, rounded and well-defined nucleus with chromatin clumps roughly distributed (Fig. 1A).

III. Oocytes with lipid vitellogenesis: initially present nucleus with single nucleolus and eccentric, cytoplasm better developed and stained then the stem cells. The formation of lipid droplets begins. This process represents lipid deposition, which occurs initially in the cortical cytoplasm near the cell membrane, extending to near the nucleus (Fig. 1B). At the end of this phase, there is an increase in cell volume and presence of large chromatin granules attached to the nuclear membrane.

IV. Vitellogenic oocytes with lipid and protein: lipid droplets occur beyond the appearance of acidophilic granules (Fig. 1C).

V. Oocytes with completed vitellogenesis:
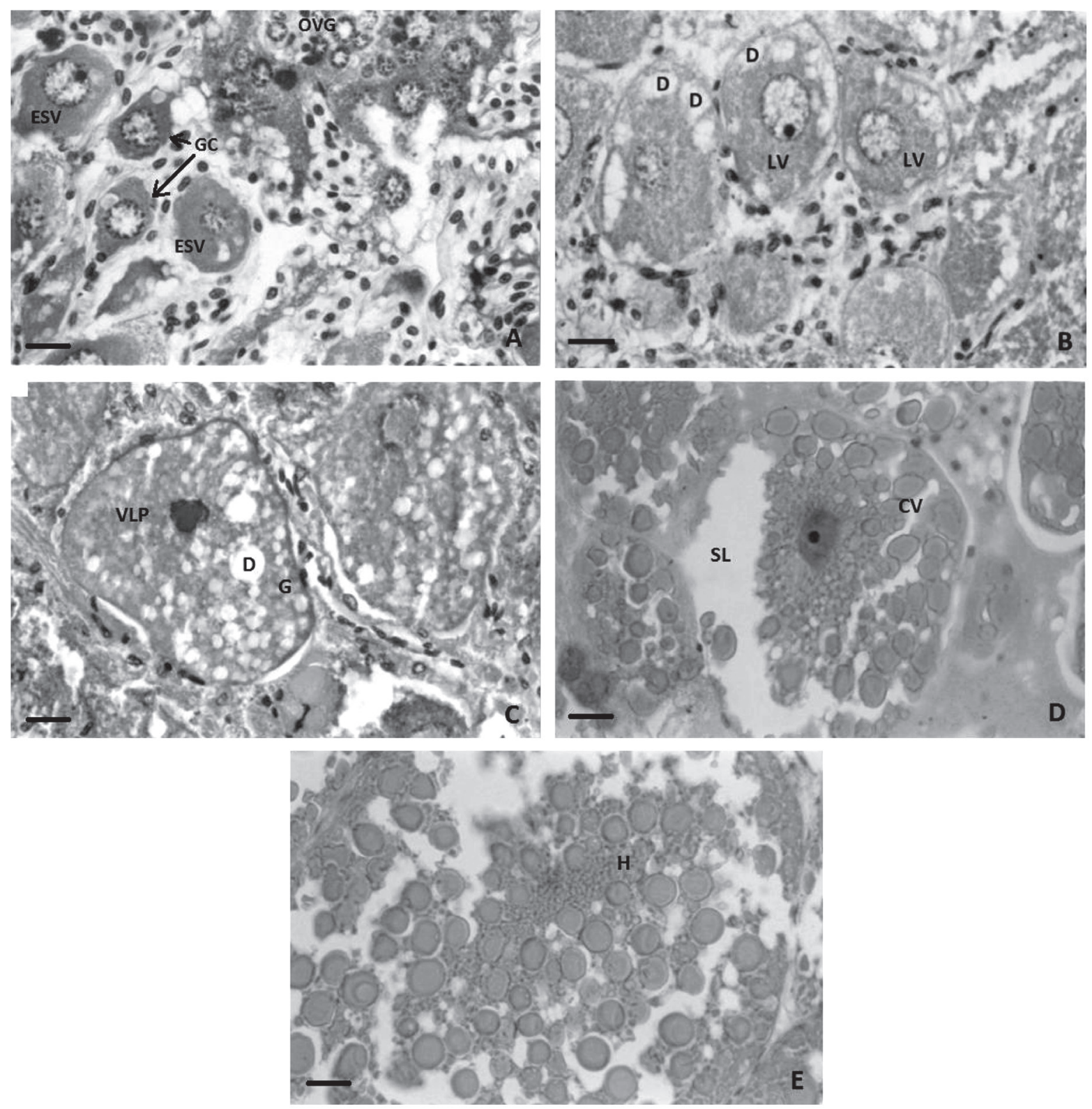

Figure 1. A- Ovary of $U$. cordatus showing oogonia grouped in a nest (OVG), oocytes of the germinative centers (GC) and oocytes in early stages of vitellogenesis (ESV); B- oocytes with lipid vitellogenesis (LV), which appears during the early formation of droplets (D) in the cortical region; C- vitellogenic oocytes with lipid- and protein (VLP)-containing droplets (D) that are distributed throughout the cytoplasm and protein granules $(\mathrm{G})$; D- oocytes with completed vitellogenesis $(\mathrm{CV})$, which causes the formation of a single lipid droplet (SL); E- oocytes in hyalinization $(\mathrm{H})$, nucleus not visible. Staining: HE. (50 X). Scale bar $=0,013 \mathrm{~mm}$. 
the nucleus is characterized by a process of reduction in its diameter and increasing size of the protein granules, which completely changes the appearance of the cytoplasm compared to the previous phase. The union of the lipid droplets occurs to form to large droplets, but less in the cytoplasm or even a single lipid droplet (Fig. 1D).

VI. Oocytes in hyalinization: a large increase in volume occurs due to the increased amount of yolk granules, which fill the cell completely (Fig. 1E).

Macroscopic observations, corroborated by observations using the light microscope (L.M.), resulted in the description of the following six gonadal stages:

I. Immature. Macroscopically, the ovaries are transparent, and there may be a variation in coloration reaching a whitish color, with an elastic consistency and little volume. Based on L.M., there is a large amount of oogonias (young germ cells) distributed just below a thin capsule of connective tissue. Trabeculae of connective tissue divide the body into pseudo-lobules. In the central organ, the germinative centers oocytes appear grouped into pseudo-lobules, occasionally in division. Such groupings are observed in all stages of development. Within the central region and the capsule, oocytes with lipid vitellogenesis in the growth process occur (Fig. 2A).

II. At maturity. Macroscopically, the color of the ovary varies from yellow to orange-red. The gonad has more volume and less elasticity when compared to the immature stage and becomes much more evident in the abdominal cavity. By L.M., the ovary has a thin capsule of connective tissue and stromal cells. Connective tissue septa divide the organ into pseudo-lobules containing oocytes in various stages of development. In the final phase of this stage, the oocytes vitellogenesis presents lipids and proteins. The ovary is located in the central region and has abundant blood vessels (Fig. 2B).

III. Mature. Macroscopically, the ovary is stained a dark red color and is very turgid. The ovary occupies much of the abdominal cavity. By L.M., at the beginning of this stage, the pseudo-lobes are very thin due to the growth of oocytes showing complete vitellogenesis, giving consistency to the fabric. Still occur oocytes of the germinative centers and oocytes with lipid vitellogenesis. However, oocytes with completed vitellogenesis predominate. The basophilia disappears almost entirely. In the final phase, hyaline oocytes appear and occupy the tissue in an irregular arrangement. The pseudo-lobes are no longer observed. These oocytes are ready to be released (Fig. 2C).

IV. Partly spawned. Macroscopically, the color varies from yellow to red, with a volume varied in the abdominal cavity and relative elasticity. When seen by L.M., the ovary is characterized by having types IV, V and VI of oocytes, indicating that there are both developing and fully developed oocytes. There is also the presence of atretic follicles and some empty spaces, indicating recent spawning (Fig. 2D).

V. Fully spawned. Macroscopically, the ovary has a whitish to yellowish color and is very flaccid, becoming elastic. By L.M., there are few oocytes of type II and many empty spaces in the tissue, corresponding to the eggs that were released during spawning. A large amount of fibrous tissue is present, and a stroma with many cells is observed. The tissue has an unstructured appearance. Atretic follicles, oocytes in the process of degeneration, are present (Fig. 2E).

VI. In recovery. Macroscopically, the ovary has a pink color, with brief and relatively elasticity. However, they are clearly larger than the immature ovaries, and they become more visible, which facilitates excision. In L.M., there are several groups of germ cells surrounded by a capsule throughout the ovarian stroma. Oocytes of type II are in small amounts throughout the tissue. The parenchyma starts to be organized into lobulated septa. This observation indicates that the ovary has no resting phase before another process of maturation begins (Fig. 2F).

Table 1 shows the occurrence of the stages during the different months of the study. The partly spawning stage occurred in January, February and March, indicating 

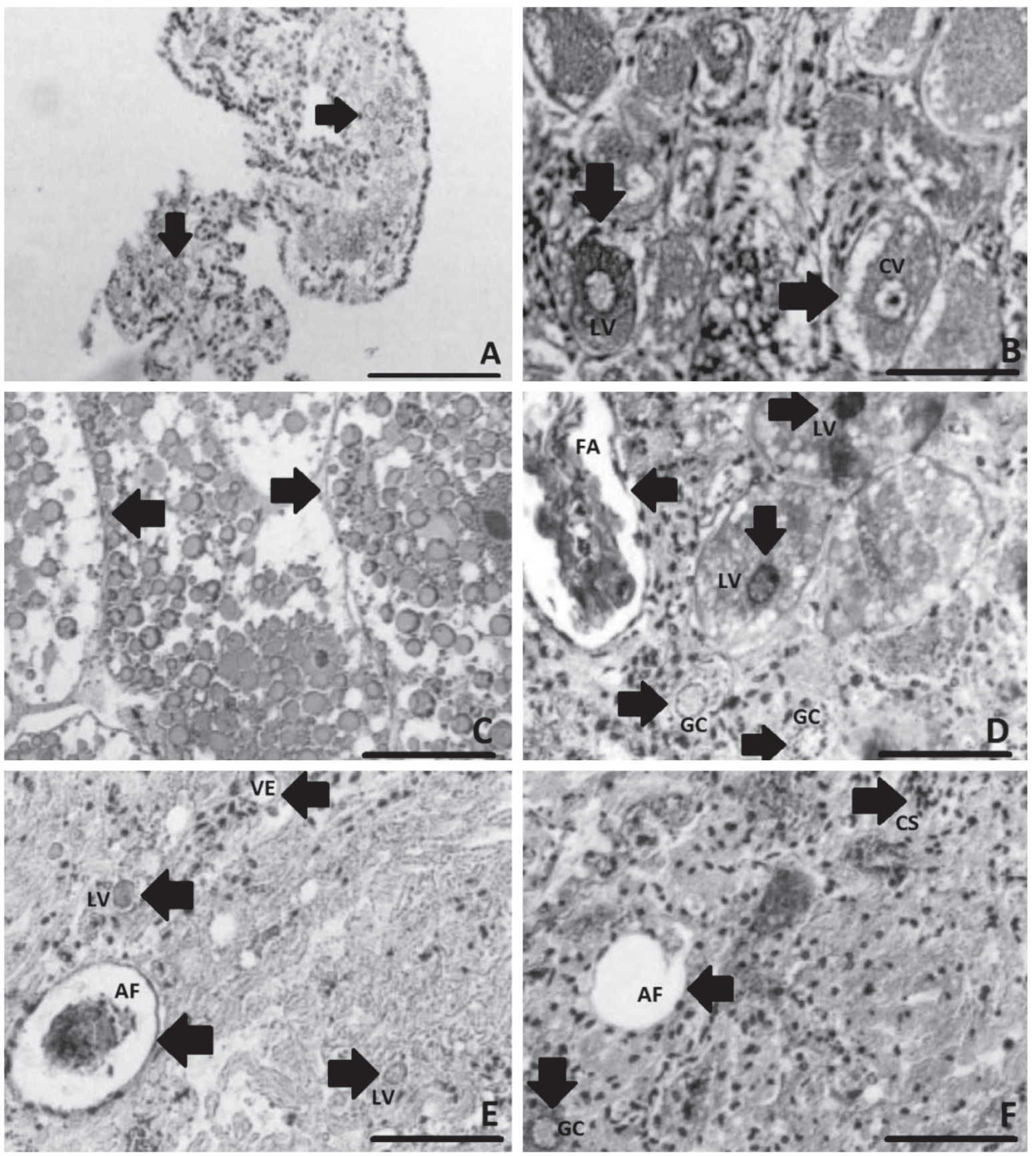

Figure 2. Maturation stages of $U$. cordatus ovary. A- immature stage, containing nests of young cells (arrow); B- early stages of maturation showing oocytes with lipid vitellogenesis (LV) and complete vitellogenesis $(\mathrm{CV})$; C-early mature stage containing oocytes with completed vitellogenesis (arrow); D- partially spawned stage, which includes the presence of oocytes with lipid vitellogenesis (LV) together with oocytes in the germinative centers (GC). Note the presence of atretic follicles (AF), indicating the process of spawning; E- completely spawned stage containing cavities left by the eggs (VE), oocytes with lipid vitellogenesis (LV) and atretic follicles (AF); F- recovery stage presenting initiation of lobe formation, highly cellular stroma (CS), oocytes in the germinative centers (GC) and atretic follicles (AF). Staining: HE. (10 X). Scale bar $=0,06 \mathrm{~mm}$.

that $U$. cordatus have multiple spawning. This fact can also be evidenced by the microscopic examination of the ovaries that showed oocytes with lipid vitellogenesis together with oocytes in the germinative centers (Fig. 2D) and the macroscopic examination that showed that the ovaries had characteristics of both mature and recovering stages.

Ovigerous females were found between January and March 1999, indicating that reproductive activity occurs during the summer. In January, the egg masses were heavier; in February, there was a uniform reduction in weight and in March, there was a 
greater variation in weight. A lower percentage of females with non-mating characteristics were present from April through August (Tab. 1). The ovaries of these females showed the same color as the mature stage; however, the consistency was different, and the volume was smaller.

\section{Discussion}

The presence of six stages of gonadal development was detected in the females of other decapod crustaceans, such as the crabs Chaceon fenneri (as Geryon fenneri) (Manning \& Holthuis, 1984) (Erdman and Blake, 1988) and Callinectes ornatus Ordway, 1863 (Mantelatto and Fransozo, 1999). The principal difference between our results and those in other studies is that the present analysis suggests that the species has multiple spawning. Therefore, the new developmental category of partly spawned ovaries was not described in previous studies.

The definition of multiple spawning is characterized by groups of mature oocytes in different phases of development at the same time during the same reproductive period (Vazzoler, 1996). The ovary exhibits features of both the mature and regenerating stages. In this study, these characteristics were observed for $U$. cordatus in 34 females between January and March (Table 1). Another characteristic of multiple spawning is the occurrence of spawning peaks. During the period of this study, a reproductive migration ("andadas") was observed during December and March. These observations support the classification of the spawning of $U$. cordatus as multiple.

The macroscopic morphology of the female reproductive system of $U$. cordatus observed in the present work is similar to that found in previous studies of this species (Mota-Alves, 1975; Nakamura, 1979) and for other decapods such as Metacarcinus magister (as Cancer magister) (Dana, 1852) (Jensen et al., 1996).

We characterized the following six stages of oocyte development: I. young germ cells (oogonias); II. oocytes of the germinative centers; III. oocytes with lipid vitellogenesis; IV. vitellogenic oocytes with lipid and protein; V. oocytes with completed vitellogenesis; and VI. oocytes in hyalinization. For the same species, Nakamura (1979) described only four types of oocytes and did not characterize oogonias and oocytes in hyalinization. The type I oocytes described by Nakamura (1979) were similar to this study's oocytes with germinative centers; type II was similar to this study's oocytes with lipid vitellogenesis; type III was similar to this study's vitellogenic oocytes with lipid and

Table 1. Number and percentage of $U$. cordatus females in each sexual stages in 1998 and 1999 in mangroves of Victoria Bay.

\begin{tabular}{|c|c|c|c|c|c|c|c|c|c|c|c|c|}
\hline Sexual stages & Oct & Nov & Dec & Jan & Feb & Mar & Apr & May & Jun & Jul & Aug & Sep \\
\hline I. Immature & - & $\begin{array}{l}10 \\
(29,4)\end{array}$ & $\begin{array}{l}3 \\
(10,7)\end{array}$ & $\begin{array}{l}3 \\
(10,7)\end{array}$ & $\begin{array}{l}3 \\
(9,4)\end{array}$ & $\begin{array}{l}4 \\
(12,5)\end{array}$ & $\begin{array}{l}3 \\
(14,3)\end{array}$ & $\begin{array}{l}1 \\
(4,5)\end{array}$ & - & - & - & $\begin{array}{l}7 \\
(28,0)\end{array}$ \\
\hline II. At maturity & $\begin{array}{l}13 \\
(81,3)\end{array}$ & $\begin{array}{l}9 \\
(26,5)\end{array}$ & - & - & - & - & - & - & - & - & $\begin{array}{l}4 \\
(26,7)\end{array}$ & $\begin{array}{l}15 \\
(60,0)\end{array}$ \\
\hline III. Mature & - & $\begin{array}{l}15 \\
(44,1)\end{array}$ & $\begin{array}{l}25 \\
(89,3)\end{array}$ & $\begin{array}{l}10 \\
(35,7)\end{array}$ & $\begin{array}{l}25 \\
(78,1)\end{array}$ & $\begin{array}{l}13 \\
(40,6)\end{array}$ & $\begin{array}{l}1^{*} \\
(4,7)\end{array}$ & $\begin{array}{l}2^{*} \\
(9,1)\end{array}$ & $\begin{array}{l}3^{*} \\
(25,0)\end{array}$ & $\begin{array}{l}2^{*} \\
(13,3)\end{array}$ & $\begin{array}{l}1^{*} \\
(6,7)\end{array}$ & - \\
\hline IV. Partly spawned. & - & - & - & $\begin{array}{l}15 \\
(53,6)\end{array}$ & $\begin{array}{l}4 \\
(12,5)\end{array}$ & $\begin{array}{l}15 \\
(46,9)\end{array}$ & - & - & - & - & - & - \\
\hline V. Fully spawned & - & - & - & - & - & - & $\begin{array}{l}17 \\
(81,0)\end{array}$ & $\begin{array}{l}17 \\
(77,3)\end{array}$ & $\begin{array}{l}7 \\
(58,3)\end{array}$ & - & - & - \\
\hline VI. In recovery & $\begin{array}{l}3 \\
(18,7)\end{array}$ & - & - & - & - & - & - & $\begin{array}{l}2 \\
(9,1)\end{array}$ & $\begin{array}{l}2 \\
(16,7)\end{array}$ & $\begin{array}{l}13 \\
(86,7)\end{array}$ & $\begin{array}{l}7 \\
(46,6)\end{array}$ & $\begin{array}{l}3 \\
(12,0)\end{array}$ \\
\hline Total of females & 16 & 34 & 28 & 28 & 32 & 32 & 21 & 22 & 12 & 15 & 12 & 25 \\
\hline
\end{tabular}

* Females with characteristics of non-mating. 
protein; and type IV was similar to this study's oocytes with completed vitellogenesis.

For the crab Halicarcinus planatus (Fabricius, 1775), only two types of oocytes were found in ovaries: small oocytes $(0.075$ - $0.1 \mathrm{~mm}$ in diameter) in pre-vitellogenesis or primary vitellogenesis and larger oocytes $(0.18-0.43 \mathrm{~mm}$ in diameter) in secondary vitellogenesis. Both types were also present during the entire study, both in adult and immature females, and ovigerous females of $H$. planatus occurred throughout the year (Diez and Lovrich, 2010). The differences in this species and $U$. cordatus may be due to the capability of $H$. planatus to develop their ovaries, whereas females of $H$. planatus are ovigerous. The type of ovarian development found in $H$. planatus is a unique feature of sub-Antarctic decapods. It is probable that this feature produces an adaptive advantage in extreme environments (Diez and Lovrich, 2010).

We described the following six stages of ovary development in this work: I. immature; II. at maturity; III. mature; IV. partly spawned; V. fully spawned; and VI. in recovery. The decision to classify ovarian development into six stages was a consequence of the macroscopic differences observed and was corroborated by the results of the histological analyses performed during the year of study. MotaAlves (1975) described five developmental stages for the females of $U$. cordatus. Stage I corresponds to the immature stage; stages II and III correspond to the stage at maturity; stage IV corresponds to mature; and stage V corresponds to the fully spawned stage. This author does not describe the partly spawned stage or the stage in recovery. The four stages described by Nakamura (1979) were similar to those found in this study: immature, at maturity, mature and fully spawned. However, the recovery and partly spawned stages were not considered despite the study's finding that the ovary initiated a new process of maturation after spawning. Dalabona and Loyola-Silva (2005) described only three stages: at maturity, mature and spawned. The comparison of our results with those of previous studies indicates that three stages are not sufficient to characterize the process of ovary maturation in $U$. cordatus. Wunderlich et al. (2008) characterized three stages of the development of the ovaries (mature, in maturation and immature) but subdivided each stage. The analysis cited only included macroscopic features.

In our studies, reproduction was observed during the summer. The occurrence of reproduction during the summer has been described in several previous studies of $U$. cordatus (Mota-Alves, 1975; Alcântara-Filho, 1978; Costa, 1979; Nakamura, 1979; Castro, 1986; Botelho et al., 1999; Ivo et al., 1999). However, it should be recognized that the known geographic distribution of $U$. cordatus includes a wide range of latitudes (Melo, 1996). It is very important to know the reproductive period of this species in each state because the laws intended to protect these crabs in Brazil are made locally. For Espirito Santo state, where this research was conducted, data on the reproduction of this species are lacking.

The reproductive activity of other decapod crustaceans occurs during the summer. However, certain species, such as Callinectes ornatus (Mantelatto and Fransozo, 1999), exhibit continuous reproduction throughout the year with peaks during the summer. The males of $U$. cordatus are physiologically capable of reproducing throughout the year (Castilho et al., 2008; Wunderlich et al., 2008). It is probable that the year-round reproduction of the males occurs because the energy cost of reproduction in males is much lower than the corresponding cost in females. Therefore, the results presented in this study indicate that multiple spawning may occur in $U$. cordatus during the same season and that the ovary rapidly restarts its development.

\section{Acknowledgements}

Thanks to Tony Vinícuis M. Sampaio for the assistance in the preparation of the figures, Maria Luisa C. López-Alverez for the access to the research infrastructure of the Laboratorio de Biologia Celular e Tecidual da Universidade 
Estadual do Norte Fluminense and Dr. Walter Boeger for revision. This research is part of a Master's thesis by Flávia Duarte Ferraz Sampaio and was partially funded by FACITEC/ Prefeitura Municipal de Vitória.

\section{References}

Alcântara-Filho, P. 1978. Contribuição ao estudo da biologia e ecologia do caranguejo-uçá, Ucides cordatus (Linnaeus, 1763) (Crustacea, Decapoda, Brachyura) no manguezal do Rio Ceará (Brasil). Arquivos de Ciências do Mar, 18(1/2): 1-41.

Alves, R.R.N. and Nishida, A.K. 2004. Aspectos socioeconômicos e percepção ambiental dos catadores de caranguejo-uçá Ucides cordatus (L., 1763) (Decapoda, Brachyura) do estuário do Rio Mamanguape, nordeste do Brasil. Interciência, 28(1): 36-43.

Botelho, E.R.O.; Dias, A.F. and Ivo, C.T.C. 1999. Estudo sobre a biologia do caranguejo-uçá, Ucides cordatus cordatus (Linnaeus, 1763), capturado nos estuários dos rios Formoso (Rio Formoso) e Ilhetas (Tamandaré), no Estado de Pernambuco. Boletim Técnico Cientifico. CEPENE, 7(1): 9-52.

Cajal, R. and Castro, F. 1972. Elementos de técnica micrográfica del sistema nervioso. Barcelona, Salvat, 283p.

Castilho, G.G.; Ostrensky, A.; Pie, M.R. and Boeger, W.A. 2008. Morphology and histology of the male reproductive system of the mangrove land crab Ucides cordatus (L.) (Crustacea, Brachyura, Ocypodidae). Acta Zoologica (Stockholm) 89: 157-161.

Castro, A.C.L. 1986. Aspectos bio-ecológicos do caranguejo-uçá, Ucides cordatus cordatus (Linnaeus 1763), no estuário do Rio dos Cachorros e Estreito do Coqueiro, São Luís MA. Boletim do Laboratório de Hidrobiologia 7:7-26.

Costa, R.S. 1979. Bioecologia do caranguejouçá, Ucides cordatus (Linnaeus, 1763) Crustacea, Decapoda - no nordeste brasileiro. Boletim da Sociedade Cearense de Agronomia 20:1-74.

Dalabona, G. and Loyola-Silva, J. 2005.
Período reprodutivo de Ucides cordatus (Linnaeus) (Brachyura, Ocypodidae) na Baía das Laranjeiras, sul do Brasil. Acta Biológica Paranaense, 34: 115-126.

Diez, M.J. and Lovrich, G.A. 2010. Reproductive biology of the crab Halicarcinus planatus (Brachyura, Hymenosomatidae) in subAntarctic waters. Polar Biology, 33: 389-401. Erdman, R.B. and Blake, N.J. 1988. Reproductive ecology of female golden crabs Geryon fenneri Manning and Holthuis, from Southeastern Florida. Journal of Crustacean Biology, 8(3): 392-400.

Ivo, C.T.C.; Dias, A.F. and Mota, R.I. 1999. Estudo sobre a biologia do caranguejo-uçá, Ucides cordatus cordatus (Linnaeus, 1763), capturado no delta do rio Parnaíba, Estado do Piauí. Boletim Técnico-Cientifico do CEPENE, 7: 53-84.

Jensen, P.C.; Orensanz, J.M. and Armstrong, D.A. 1996. Structure of the female reproductive tract in the dungeness crab (Cancer magister) and implications for the mating system. The Biological Bulletin, 190 (3): 336-349.

Junqueira, L.C.U. and Junqueira, L.M.M.S. 1983. Técnicas básicas de citologia e histologia. São Paulo, Livraria Editora Santos, 123p.

Lillie, R.D. and Fulmer, H.M. 1976. Histopathologic technic and practical histochemistry. New York, Mc Graw-Hill, 942p.

Mantelatto, F.L. and Fransozo, A. 1999. Reproductive biology and moulting cycle of the crab Callinectes ornatus (Decapoda, Portunidae) from the Ubatuba region, São Paulo, Brazil. Crustaceana, 72(1): 63-76.

Melo, G.A.S. 1996. Manual de identificação dos Brachyura (caranguejos e siris) do litoral brasileiro. São Paulo, Pleiade/FAPESP, 604p.

Mota-Alves, M.I. 1975. Sobre a reprodução do caranguejo-uçá, Ucides cordatus (Linnaeus), em mangues do Estado do Ceará - Brasil. Arquivos de Ciências do Mar, 15(2): 85-91.

Nakamura, I.T. 1979. Sobre a fenologia de Ucides cordatus (L. 1763), Crustacea - Brachyura, da Baía de Paranaguá. Dissertação de Mestrado. Universidade Federal do Paraná, Curitiba. $71 \mathrm{p}$. 
Nascimento, S.A. 1993. Biologia do caranguejouçá (Ucides cordatus). Aracaju, Adema, 48p.

Nordi, N. 1995. O processo de comercialização do caranguejo uçá (Ucides cordatus) e seus reflexos na atitude de coleta. Revista Nordestina de Biologia, 10(1): 39-45.

Sant'Anna, B.S; Pinheiro, M.A.A; Mataqueiro, M. and Zara, F.J. 2007. Spermathecae of the mangrove crab Ucides cordatus. Journal of the Marine Biological Association of the United Kingdom, 87: 903-911.

Vale, C.C. 1994. Homens e caranguejos: uma contribuição geográfica ao estudo dos manguezais da Baía de Vitória (ES) como fonte de alimento. Anais do III Simpósio de Ecossistemas da Costa brasileira. Subsidios a um gerenciamento ambiental. (1): 268-273.

Vazzoler, A.E.A.M. 1996. Biologia da reprodução de peixes teleósteos: teoria e prática. Maringá, EDUEM, 169p.

Wunderlich, A.C.; Pinheiro, M.A.A. and Rodrigues, A.M.T. 2008. Biologia do caranguejo-uçá, Ucides cordatus (Crustacea: Decapoda: Brachyura), na Baía da Babitonga, Santa Catarina, Brasil. Revista Brasileira de Zoologia, 25(2): 188-198. 